women who want part-time posts to combine with their families will be pushed into the background unless provision for such posts is built into the system as a mandatory requirement and not as a grace-and-favour option. Close to half of new medical graduates are now women, over half of whom marry in their 20 s; three-quarters of all women doctors in their 30s are married. Even if only half of the coming generation of women doctors have children and want to continue their postgraduate training at the same time, that will mean that $25 \%$ of the training posts available should be arranged for part-time staff. The Oxford report draws attention to the sort of back-up needed if women are to be able to make use of such opportunities-child-minding facilities, study leave geared to the special requirements of parents of small children, and so on. Manpower calculations will need to be based more closely on whole-time equivalents when a substantial proportion of the medical workforce under the age of 50 is working part time.

1 Department of Health and Social Security. Contracts of consultants and other senior hospital medical staff. PM(79)11. London: DHSS, 1979.

2 Department of Health and Social Security. Medical manpower-the next twenty years. London: DHSS, 1978.

${ }^{3}$ Medical Women's Federation. Postgraduate training and career structure in the hospital specialties. London: Medical Women's Federation, 1980.

4 Nabarro JDN. Hospital staffing in the 1980s. (Copies obtainable from the BMA Secretariat.)

5 British Medical Association. Medical manpower, staffing, and training requirements. London: BMA, 1979.

${ }^{6}$ Department of Health and Social Security. Medical manpower steering group report. London: DHSS, 1980.

\section{Hormone receptors and human breast cancer}

Endocrine manipulation causes regression of the tumour in about one-third of patients with metastatic breast cancer, but the responders cannot be selected accurately by clinical or histological features. The effect of a hormone is determined by its circulating concentration and the responsiveness of the end organ, which itself depends on a functional receptor mechanism. Breast cancer presents a striking example of a tissue that varies in its responsiveness to hormones, and it is the first disease in which estimation of tissue receptors can be used to predict the effect of treatment.

Specific high-affinity binding for oestradiol is detectable over a wide range of concentrations in extracts from the tumours of $60-70 \%$ of patients with metastatic breast cancer. ${ }^{1-3}$ Regression with endocrine treatment occurs in about half the patients with tumours that give positive results but in only one in 10-20 of those with undetectable binding. ${ }^{4}$ With such odds ablative surgery is unjustifiable in patients with oestrogenreceptor-negative tumours. Some progress has been made in identifying more precisely those tumours with detectable receptors that are sensitive to hormones. For example, those with relatively high concentrations of oestrogen receptor are more likely to be responsive. ${ }^{1-3}$ Oestrogen binding varies between tumour cells even in a single histological section, ${ }^{5}$ and some oestrogen-receptor-positive tumours which nevertheless prove unresponsive may have a large fraction of cells that do not contain receptor or have too low a concentration to confer responsiveness. But the concentration of receptor is not the only factor, as response rates do not exceed $80 \%$ even in tumours with relatively high concentrations. Trans- location of the oestradiol-receptor complex to the nucleus may be defective in about half the tumours with receptor, ${ }^{6}$ and they are less likely to be responsive to hormones. ${ }^{7}$ Progesterone receptor, which in other tissues is dependent on oestrogen stimulation, is rarely found in tumours in which oestrogen receptor is undetectable; the response rate of tumours containing both types of receptor is about $75 \%{ }^{1}$

Testing for receptors will be important for selecting patients if antioestrogen treatment is found to be beneficial when given as an adjunct to mastectomy. Improvements in techniques of tumour collection and estimation of receptors have increased the proportion of tumours found positive on testing, ${ }^{8}$ but a small proportion remains of responsive tumours in which receptors are undetectable. ${ }^{1}$ As a result many clinicians believe that treatment with antioestrogens should be given for a trial period to all patients. In current clinical practice estimation of receptors is probably best restricted to patients entering clinical trials who are to be stratified on the basis of the results. Estimation of oestrogen receptor in all tumour specimens ${ }^{10}$ would mean that patients were well documented for future research, but the cost seems unjustifiable without more definite evidence of long-term benefit to patients.

Though the clinical applications of receptor estimation are becoming clearer, ${ }^{9}$ the mechanisms by which changes in the hormonal environment cause regression of the tumour are more complex. For example, recurrence of growth after a period of hormone-induced remission may be followed by regression with a change of hormone treatment or even after withdrawal of the treatment that was initially successful. This suggests that tumours may undergo a qualitative change in responsiveness to hormones, possibly by overgrowth of better-adapted cells. Moreover, not all responses are likely to be mediated through oestrogen receptor; and yet estimation of oestrogen receptor predicts the response to endocrine manipulation as diverse as oophorectomy, hypophysectomy, and treatment with androgens and corticosteroids. ${ }^{4}$ Receptors for oestradiol, progesterone, testosterone, and cortisol tend to occur in the same tumours ${ }^{11}$ and the reason that tumours with oestrogen receptor are sensitive to hormones other than oestrogens or their antagonists may be that oestrogen receptor is directly associated with other receptors by receptor regulatory mechanisms. Alternatively, the association between receptors and their functional capacity, the morphological features of differentiation such as tubule and acinar formation, ${ }^{12} 13$ and the synthesis of specialised proteins ${ }^{14}$ may all arise because some tumours are sufficiently differentiated to manifest features of normal breast tissue.

We do not know how far differentiation is under endocrine control, but studies linking receptors and hormone-dependent proteins with morphological and clinical features may help the recognition of hormone-sensitive tumours; and-more important-they may lead to better understanding of the control mechanisms, both intact and defective, that influence growth of breast tumour cells.

1 McGuire WL. Hormone receptors: their role in predicting prognosis and response to endocrine therapy. Semin Oncol 1978;5:428-33.

2 DeSombre ER, Greene GL, Jensen EV. Estrophilin and endocrine responsiveness of breast cancer. In: McGuire WL, ed. Hormones, receptors and breast cancer. New York: Raven Press, 1978:1-14.

3 Allegra JC, Lippman ME, Thomson EB, et al. Estrogen receptor status: an important variable in predicting response to endocrine therapy in metastatic breast cancer. Eur f Cancer 1980;16:323-31.

4 McGuire WL, Carbone PP, Sears ME, Escher GC. Estrogen receptors in human breast cancer: an overview. In: McGuire WL, Carbone PP, Wollmer EP, eds. Estrogen receptors in human breast cancer. New York: Raven Press, 1975:1-9.

5 Walker RA, Cove DH, Howell A. Histological detection of oestrogen receptor in human breast carcinomas. Lancet 1980;i:171-3. 
- Laing L, Smith MG, Calman KC, Smith DC, Leake RE. Nuclear oestrogen receptors and treatment of breast cancer. Lancet 1977 ;ii:168-9.

${ }^{7}$ Leake RE, Macbeth F, Smith DC, Calman KC, Laing L. Steroid hormone receptor status as an index of prognosis and in therapy selection. Cancer Treat Rep $1979 ; 63: 1188$.

${ }^{8}$ LeClercq G, Heuson JC, Deboel MC, Mattheiem WH. Oestrogen receptors in breast cancer: a changing concept. Br Med $\mathcal{F} 1975$;i:185-9.

- A statement by the British Breast Group and colleagues. Steroid receptor assays in human breast cancer. Lancet $1980 ; \mathrm{i}: 298-300$.

${ }^{10}$ Henderson IC, Cancellos GP. Cancer of the breast: the past decade. $N$ Englf Med 1980;302:78-90.

11 Allegra JA, Lippman ME, Thompson EB, et al. Distribution, frequency and quantitative analysis of estrogen, progesterone, androgen and glucocorticoid receptors in human breast cancer. Cancer Res $1979 ; 39$ 1447-54.

12 Maynard PV, Davies CJ, Blamey RW, Elston CW, Johnson J, Griffiths K. Relationship between oestrogen-receptor content and histological grade in human primary breast tumours. $B r F$ Cancer $1978 ; 38: 745-8$.

13 Fisher ER, Redmond MK, Liu M, Rockette H, Fisher B. Correlation of oestrogen receptor and pathologic characteristics of invasive breast cancer. Cancer 1980;45:349-53.

14 Woods KL, Cove DH, Howell A. Predictive classification of human breast carcinomas based on lactalbumin synthesis. Lancet 1977;ii:14-6.

\section{Leukaemic tumefaction in soft tissues}

All types of leukaemia may give rise to tumours in sites not normally associated with haemopoiesis or lymphopoiesis. Chloroma (granulocytic sarcoma) results from the localised proliferation of myelogenous leukaemia cells; lymphocytic sarcoma derives from the cells of acute or chronic lymphocytic leukaemia. Extramedullary acute lymphocytic leukaemia occurs most frequently in the central nervous system and gonads, ${ }^{1}$ and is found in a high proportion of patients. In contrast, pigmented (chloromas) and non-pigmented granulocytic sarcomas may occur anywhere in the body, and their incidence is low: one study found granulocytic sarcomas in only $3.1 \%$ of 478 patients with acute or chronic myelogenous leukaemia. ${ }^{2}$ Granulocytic sarcomas are found most often in bones, particularly those of the face and cranium. The ribs, vertebrae, and pelvis may also be affected, but granulocytic sarcomas of the long bones are seen less often. The brain and spinal cord are never directly invaded, though extradural tumours may cause neurological symptoms. Tumour formation is rare in organs such as the liver, pancreas, thyroid, and breasts. ${ }^{3-6}$

Why there should be both generalised and localised phases of leukaemic cell growth remains unknown. Growth of a single tumour might be determined by local factors, but the presence of multiple deposits in different sites makes this explanation unlikely. Factors related to the leukaemic cells themselves seem more probable determinants. Differentiation of normal haemopoietic cells is associated with the development and loss of cell-surface antigens. ${ }^{78}$ Normal haemopoietic stem cells in the peripheral blood of the mouse, for example, are antigenically different from those in the bone marrow, ${ }^{9}$ which suggests that cell-surface properties may be one factor determining the release of stem cells from the marrow cavity. Furthermore, studies of Moloneyvirus leukaemia in mice have shown that interactions with viruses may result in the appearance of virus-specific surface antigens, which may vary in density in individual leukaemias. ${ }^{10} 11$ Indeed, some forms of virus-induced murine leukaemia may start as a solid tumour. ${ }^{12}$ Thus one possible explanation for the different distributions of leukaemic cells might be the acquisition of inappropriate differentiation-associated antigens or virus-àssociated antigens.
The occurrence of extramedullary acute lymphoblastic leukaemia in pharmacological "sanctuaries" such as the central nervous system and testis, ${ }^{1}$ and, less frequently, the anterior chamber of the eye, ${ }^{13}$ remains an important clinical complication. Vigorous measures are taken routinely nowadays to eradicate these cells. In contrast, though tumours have occasionally been reported to antedate the appearance of leukaemia, ${ }^{14} 15$ most granulocytic sarcomas are found at necropsy. There is no firm evidence for the preferential occurrence of granulocytic sarcomas in sanctuary sites, though the tendency for acute myelogenous leukaemia to recur at an original extramedullary site ${ }^{16}$ suggests that the tumour cells may be protected or resistant to chemotherapy. Since the unpredictable nature of granulocytic sarcomas does not permit prophylactic treatment they have to be treated locally as and when they are discovered. On the rare occasions that a granulocytic sarcoma presents without evidence of leukaemic change in the bone marrow, the leukaemia-free marrow might in theory be harvested in advance of medullary disease and stored in liquid nitrogen. More aggressive chemotherapy could then be given, with later infusion of the patient's own haemopoietic stem cells.

${ }^{1}$ Hustu HO, Aur RJA. Extramedullary leukaemia. Clinical Haematology 1978;7:313-37.

2 Muss HB, Moloney WC. Chloroma and other myeloblastic tumours. Blood 1973;42:721-8.

3 Dameshek W, Gunz F. Leukemia. 2nd ed. New York: Grune and Stratton, 1964.

4 Liu PI, Ishimaru T, McGregor DH, Okada H, Steer A. Autopsy study of granulocytic sarcoma (chloroma) in patients with myelogenous leukemia. Hiroshima-Nagasaki 1949-1969. Cancer 1973;31:948-55.

${ }^{5}$ Viadana E, Bross IDJ, Pickren JW. An autopsy study of the metastatic patterns of human leukemias. Oncology $1976 ; 35: 87-96$.

${ }^{6}$ O'Donnell JR, Farrell MA. Acute myelogenous leukaemia with bilateral mammary gland involvement. $\mathcal{F}$ Clin Pathol 1980;33:547-51.

7 Winchester RJ, Ross GD, Jarowski CI, Wang CY, Halper J, Broxmeyer HE. Expression of Ia-like antigen molecules on human granulocytes during early phases of differentiation. Proc Natl Acad Sci USA 1977; 74:4012-6.

${ }^{8}$ Fitchen JH, Cline MJ. Human myeloid progenitor cells expressing HLA antigens. Blood $1979 ; 53: 794-7$.

$\checkmark$ Monette FC, Stockel JB. Blood-borne stem cells are immunologically distinct from those in other hematopoietic tissues. Exp Hematol 1980; 8:89-95.

${ }^{10}$ Fenyo EM. Expression of Moloney leukemia virus controlled cell surface antigen in relation to virus release. Transplant Proc 1971;3:1185-8.

${ }^{11}$ Klein G, Klein E. Antigenic behaviour of Moloney lymphomas: independence of virus release and immunosensitivity. Science 1964;145: 1316-7.

${ }^{12}$ Dunn TB. Normal and pathological anatomy of reticular tissue in laboratory mice, with classification and discussion of neoplasms. $\mathcal{F}$ Natl Cancer Inst $1954 ; 14: 1281-433$.

${ }^{13}$ Ninane J, Taylor D, Day S. The eye as a sanctuary in acute lymphoblastic leukaemia. Lancet 1980 ; i:452-3.

${ }^{14}$ Hurwitz BS, Sutherland JC, Walker MD. Central nervous system chloromas preceding acute leukemia by one year. Neurology 1970;20: 771-5.

15 Mason TE, Demaree RS, Margolis CI. Granulocytic sarcoma (chloroma), two years preceding myelogenous leukemia. Cancer 1973;31:423-32.

${ }^{16}$ Chapman P, Johnson SA. Mastoid chloroma as the first site of relapse in acute myelogenous leukaemia. $\mathcal{F}$ Laryngol Otol (in press).

\section{Correction}

\section{Interferon: therapeutic fact or fiction for the '80s?}

We much regret that an error occurred in the Regular Review on "Interferon : therapeutic fact or fiction for the ' 80 s ?" by G M Scott and D A J Tyrrell (28 June, $p$ 1558). In fact, in the study of renal transplant recipients given interferon as a prophylaxis against reactivation of viral infections, ${ }^{26}$ interferon was given twice weekly, not daily as stated in the text and table. 